\title{
LINKAGE OF REX WITH SHAKER-2 IN THE HOUSE-MOUSE
}

\author{
BY D. S. FALCONER * \\ Department of Genetics, University of Cambridge
}

Received 2.i.47

THE dominant hair-waving gene, Rex, is one of five genes with almost identical phenotypic effects, known in the house-mouse. It arose in the fancy, and was first investigated by Crew and Auerbach (1939, 1940). Linkage tests with io other loci were made and no significant departure from independent segregation was obtained. The recombination frequencies, calculated from the data published by Grew and Auerbach, are set out in table I, together with an

TABLE I

Recombination between Rex and Io other loci, with approximate values for the closest admissible linkage. Calculated from the data of Crew and Auerbach (1939, 1940)

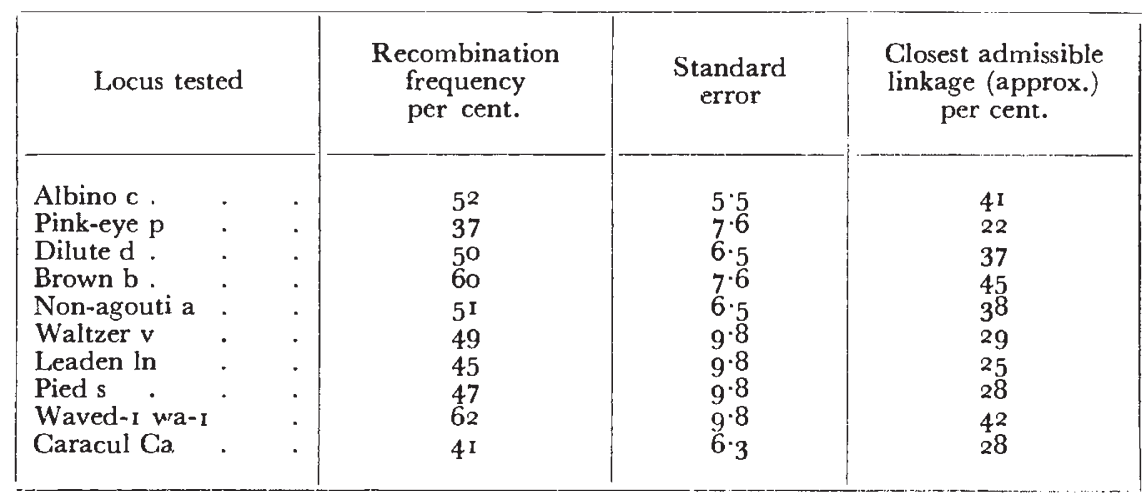

approximate value of the closest admissible linkage. Close linkage of Rex with any one of these ten factors was thus excluded, and at the same time the non-allemorphism of Rex with Caracul and with waved-I, two of the other hair-waving genes, was proved. The degree of independence of Rex with the agouti locus that was observed excludes the possibility of Rex being an allele of wellhaarig, a recessive hair-waving gene, since wellhaarig is linked with agouti with a recombination frequency of about 15 per cent. (Hertwig, 1942).

The present paper gives evidence which shows that Rex is fairly closely linked with shaker-2, a locus not tested by Crew and Auerbach. At the same time it is shown that Rex is not an allele of waved-2, the fifth hair-waving gene, which is also carried on this chromosome. (Snell and Law, I939).

* Holder of a Research Grant from the Agricultural Research Council. 
The linkage of Rex with shaker-2 was revealed by number nine of the segregating lines set up in the Department of Genetics by Professor R. A. Fisher with the object, amongst others, of filling the gaps in our knowledge of linkage. The foundation matings of this line were made by Mrs V. P. Leonard in June 1944. In pursuance of the same scheme, Rex was introduced to the line by Miss M. E. Wright early in 1945 , and in June of that year the first mating was made showing simultaneous segregation of Rex and shaker-2 in the same animal. The frequency of recombination between Rex and shaker-2, indicated by the data up to the time of going to press, is 20 per cent., with a standard error of 5.1 per cent. All the matings were coupling backcrosses of the type $\frac{\operatorname{Re}+}{+ \text { sh-2 }} \times \frac{+ \text { sh-2 }}{+ \text { sh-2 }}$, and the frequencies of the phenotypic classes among the progeny are shown in table 2. The matings are separated according to the sex of the segregating parent: the sex-difference in crossing-over is not significant.

TABLE 2

Coupling backcross segregation of Rex and shaker-2

\begin{tabular}{|c|c|c|c|c|c|c|c|}
\hline \multicolumn{2}{|c|}{$\begin{array}{c}\text { Sex of segregating } \\
\text { parent }\end{array}$} & \multicolumn{2}{|c|}{$\begin{array}{l}\text { Old combinations } \\
\operatorname{Re}+\quad+\text { sh-2 }\end{array}$} & \multicolumn{2}{|c|}{$\begin{array}{l}\text { Recombinants } \\
\operatorname{Re} \text { sh-2 }++\end{array}$} & \multirow{2}{*}{$\begin{array}{c}\text { Total } \\
3^{8}\end{array}$} & \multirow{2}{*}{$\begin{array}{c}\begin{array}{c}\text { Recombination } \\
\text { frequency } \\
\text { per cent. }\end{array} \\
18.4\end{array}$} \\
\hline Male. & . & 17 & 14 & 3 & 4 & & \\
\hline Female & . & 6 & 12 & 3 & 2 & 23 & $21 \cdot 7$ \\
\hline Combined & . & 23 & 26 & 6 & 6 & $6 !$ & $19 \cdot 67$ \\
\hline
\end{tabular}

The recessive hair-waving gene, waved-2, is known from the data of Snell and Law (1939) to be linked with shaker-2. The recombination frequency for males, based on $5^{6}$ mice bred from backcrosses was 27 per cent., and that for females, based on $25^{6}$ mice, was 25 per cent. The recombination frequency estimated from the combined data is $25 \cdot 3$ per cent. (S.E. $=2 \cdot 46$ per cent.). In order to determine the position of Rex relative to shaker-2 and waved-2, coupling backcross matings of the type $\frac{\mathrm{Re}++\mathrm{t} q}{+ \text { sh-2 wa-2 }} \times \frac{+ \text { sh-2 wa-2 }}{+ \text { sh-2 wa-2 }} \delta$ were set up. The progeny could of course be only partially classified, since Rex and waved-2 phenotypes can be distinguished only with difficulty, if at all, and the double mutant phenotype is unknown. The appearance of a single straight-haired offspring would, however, show Rex and waved-2 to be at different loci, and the frequency of straight-haired offspring would lead to an estimate of the frequency of recombination between $\operatorname{Rex}$ and waved-2, and so indicate the order of the three loci on the chromosome. 
Up to the time of going to press, 122 mice have been bred from these matings, and 25 were straight-haired. (1o of these lived to be classified as shaker-2 and II as non-shaker.) Thus Rex is shown not to be allelomorphic with waved-2, and the data indicate a frequency of $4^{\mathrm{I}}$ per cent. (S.E. $=8.9$ per cent.) for recombination between Rex and waved-2, on the assumption that the double mutant is viable. Rex therefore cannot lie close to waved-2, and the order must be $\mathrm{Re}-$ sh-2--wa-2.

Thus the map of chromosome VII of the house-mouse becomes approximately as follows :-

Map-distance (centimorgans) . . . $\leftarrow 21 \cdot 5 \rightarrow \leftarrow 27 \cdot 5 \rightarrow$ Order of genes . . . . . . Re-sh-2-wa-2 Recombination frequency (per cent.) . . $\quad \leftarrow 20 \pm 5 \rightarrow \leftarrow 25 \pm 2 \cdot 5 \rightarrow$

The map-distances are calculated according to Kosambi (1944) by means of the $r$ to $z$ transformation (Fisher and Yates, table VII). The table is entered with twice the recombination fraction as $r$ : the corresponding value of $z$ is then twice the map-distance.

The observed recombination frequencies for the two short segments indicate a map-distance of 49 centimorgans for the $\mathrm{Re}-$ wa-2 segment. This corresponds with a recombination frequency of 37.5 per cent., from which the observed frequency of $4 \mathrm{I}$ per cent. differs by less than the standard error of the estimate. The length of the $\mathrm{Re}-\mathrm{sh}-2$ segment is not, however, determined very exactly by the data presented here, and further work is in progress in the laboratory.

Thanks are due to Professor R. A. Fisher, Sc.D., F.R.S., for permission to publish the data contained in table 2, which are taken from the records of the Department of Genetics, Cambridge University.

\section{REFERENCES}

Crew, F. A. E., and Auerbach, Ch. 1939. 7. Genet., 38, 341-344.

" " " " I940. Ibid., 39, 225-227.

Fisher, R."A., AND Yates, F. . . . 1943. Statistical Tables. Edinburgh.

Hertwig, P. . . . . . . . 1942. Z. indukt. Abstamm. VererbLehre, 8o,

220-246.

Kosambi, D. D. . . . . . . 1944. Ann. Eugen., 12, 1 72-1 75.

SNell, G. D., And LaW, Ll. W. 1939. 7. Hered., 30, 447. 